\title{
Selection and validation of marker set for selection of resistant varieties of cowpea to Cowpea Aphid-borne Mosaic Virus (CABMV) in Burkina Faso
}

\author{
BARRO Antoine ${ }^{1 *}$, KIEBRE Zakaria ${ }^{2}$, BATIONO-KANDO Pauline ${ }^{2}$, TIGNEGRE Jean Baptiste De La Salle ${ }^{3}$, \\ BATIENO Téyouré Benoit Joseph ${ }^{4}$, ZIDA Félicien Marie Serge ${ }^{4}$ et SAWADOGO Mahamadou2, \\ 1 Université de Dédougou, BP 176 Dédougou, Burkina Faso \\ 2 Université Ouaga I Pr Joseph KI-ZERBO; 03 BP7021 Ouagadougou 03; Burkina Faso \\ ${ }^{3}$ World Vegetable Center (AVRDC), BP 320, Bamako, Mali. \\ 4 Institut de l'Environnement et de Recherches Agricoles, BP 476, Ouagadougou, Burkina Faso \\ *Auteur correspondant: antoine.barro@yahoo.fr; Tel: +22670974087
}

Original submitted in on $10^{\text {th }}$ May 2018. Published online at www.m.elewa.org on $31^{\text {st }}$ August 2018 https://dx.doi.org/10.4314/jab.v128i1.8

\begin{abstract}
Objective: This study aims to validate of marker set for selection of resistant varieties of Cowpea Aphid-borne Mosaic Virus.

Methodology and results: A molecular characterization of five genotypes using seventeen (17) SSR markers was carried out.

Conclusion and application of results: This study make it possible to identify four (4) polymorphic microsatellite markers (VM30, VM33, VM68 and VM70), that is to say a rate of $23,52 \%$ of polymorphism versus $76,47 \%$ of monomorphism. Two of the polymorphic markers- VM68 and VM30 were submitted to the test of validation. At the end of this test, VM68 was codominant, because it makes it possible to distinguish the heterozygous individuals $\left(F_{1}, B C_{1} F_{1}\right)$ from the homozygous individuals $\left(F_{2}\right)$ while the marker VM30 was dominating. The marker VM68 was validated and proposed in selection assisted by the markers of cowpea for resistance to CABMV.
\end{abstract}

Key words: cowpea, Cowpea Aphid-borne Mosaic Virus ((CABMV), Microsatellites, Validation, Burkina Faso.

\section{INTRODUCTION}

Several studies were carried out and made it possible to know the inheritance of cowpea resistance to Cowpea Aphid-borne Mosaic Virus (Orawu M., 2007 and Barro et al., 2016). These results were very significant for the development of resistant varieties to the CABMV. However, their application for the recurring selection (or any other classic method of selection) is rather tedious and requires much time. In fact, in traditional breeding practice, an artificial inoculation is used for the selection of resistant varieties of cowpea to CABMV.
This traditional method requires a long time of work and is expensive. Nowadays, the marker-assisted selection constitutes a palliative solution to reduce the working time considerably (Young, 2000). It allows the localization of genes responsible of the resistance of diseases or the characters of interest. In the farmers' studies, seventeen (17) markers have been identified which are associated to the cowpea resistance to the CABMV (Barro et al., 2016). For an efficient use of them, it is important to complete this study by identification and validation of which the 
codominant, i.e. that allow to recognize the heterozygotes individuals. The main objective is to contribute to the fight against the CABMV, by the assisted-markers selection for easy identification of resistant varieties of cowpea to the CABMV. The study will try (i) to identify polymorphic codominant

\section{MATERIAL AND METHODS}

Plant Material: This study concern first five lines of cowpea of which two are resistant (KVx396-4-5-2D, $\mathrm{KV} \times 640)$ - one with intermediate resistance (KVx61-1) and two susceptible (KVx30-309-6G ,Gorom local) to CABMV Then, five plants $F_{1}$ (hybrid heterozygous) resulting from various crossings KVx61-1 X KVx30-309-6G, KVx61-1 X KVx640, Gorom local X KVx61-1, KVx30-309-6G X $K V \times 396-4-5-2 D$ and finally five plants $F_{2}$ (homozygous) and one plant retro-cross $\left(\mathrm{BC}_{1} \mathrm{~F}_{1}\right.$, heterozygous) resulting also from the same types of crossings.

Laboratory Equipment: They are the polymorphic microsatellite markers used by Li et al., (2001) and BARRO A. (2013). They are the pairs of starter VM3, VM5, VM11, VM12, VM13, VM14, VM19, VM22, VM25, VM26, VM27, VM30, VM31, VM33, VM37, VM68 and VM70. For the DNA extraction, FTA cards, a buffer solution FTA, solution TBE, Eppendorf tubes were used. A thermocycler of mastercycler gradient mark was useful for the realization of the reactions in chain by the polymerase enzyme (PCR.)

Obtaining the retro-crossing plants: Five lines of cowpea- KVx396-4-5-2D, KVx640, KVx61-1, KVx30-309$6 G$ and Gorom local were crossed between themselves and a combination of twenty $F_{1}$ individuals was obtained. They are the $F_{1}$ individuals that were used to obtain the $\mathrm{BC}_{1} \mathrm{~F}_{1}$ by using the receiver parents of gene. markers linked to resistance to CABMV allowing the follow-up of the presence of gene with homozygous as well as heterozygous and (ii) to validate the markers codominants linked to gene of cowpea resistance to CABMV for selection objectives.

Total DNA Extracting: The totals genomic DNA of five lines fixed of cowpea- KVx640, KVx396-4-5-2D (resistant to CABMV), $\mathrm{KVx}$ 61-1 (with intermediate resistance to CABMV), KV $\times 30-309-6 \mathrm{G}$ and Gorom local (susceptible to CABMV) were extracted from young leaves freshly picked first for the polymorphism test. Then with the heterozygous descendants $\left(F_{1}\right.$ and $\left.\mathrm{BC}_{1} \mathrm{~F}_{1}\right)$ and homozygous $\left(F_{2}\right)$ for the identification of the microsatellite markers linked to gene resistance of cowpea to CABMV. For this, FTA card method of DNA extraction was used. It is a method, which allowed us to go faster from the extraction of DNA to the PCR. It consists in taking the fresh Young leaves and to crush them on the rough part (square) of the FTA card. The sample is dried for 30 minutes and then disks of $1 \mathrm{~mm}$ diameter are extracted there and placed in Eppendorf tubes. To each taken sampler $200 \mathrm{ml}$ of FTA buffer is added in each sample. They are incubated at room temperature for 5 minutes $(\mathrm{mn})$. This operation is repeated two or three times by renewing the buffer. At the end, the disks are rinsed with $200 \mathrm{ml}$ of TE buffer ( $10 \mathrm{mM}$ Tris-HCL, $0.1 \mathrm{mM}$ EDTA, pH 8.0), then dried for 5 minutes before transferring each disk directly into an Eppendorf tube for the polymerase chain reaction (PCR).

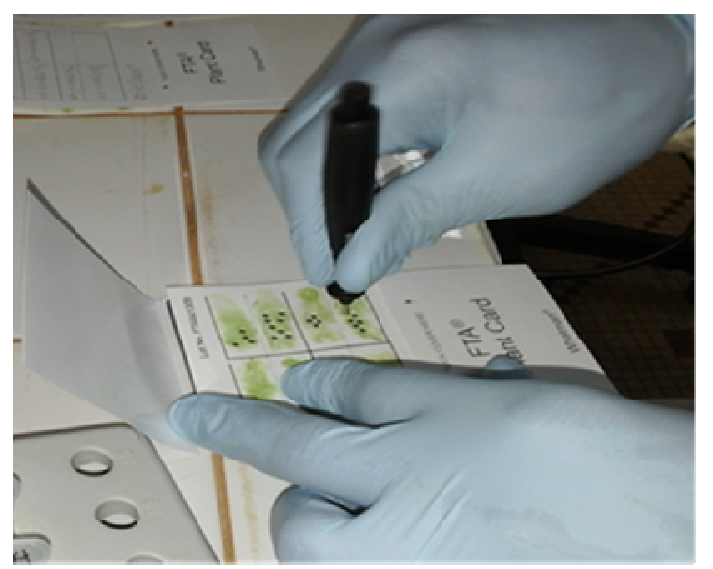

Figure 1: DNA Extraction method 
Amplification of the polymerase reaction chain (PCR) of the genomic DNA : The DNA amplification was executed with the thermocycler Eppendorf Master Cycler Gradient in a volume of $25 \mu$ containing $5 \mu$ of premix (with $1 \mathrm{U}$ of Taq polymerase, $250 \mu \mathrm{M}$ of dNTPs, $10 \mathrm{mM}$ of Tris- $\mathrm{HCl}, 30 \mathrm{mM}$ of $\mathrm{KCl}, 1.5 \mathrm{mM}$ of $\mathrm{MgCl} 2), 1 \mu \mathrm{l}$ of each primer microsatellite right and left of the seventeen samples separately (VM3, VM5, VM11, VM12, VM13, VM14, VM19, VM22, VM25, VM26, VM27, VM30, VM31, VM33, VM37, VM68, VM70), $18 \mu$ l of ultrapure water and the DNA for each sample. A marker of molecular weight of $50 \mathrm{bp}$ (base pairs) was used, as a reference tube and one control tube without DNA were included. The method was essentially based on the use of the amplification technique by polymerization in chain (PCR). The amplification program includes an initial denaturation phase at $94^{\circ} \mathrm{C}$ for 2 minutes, $94^{\circ} \mathrm{C}$ denaturation for 45 seconds and a hybridization phase at $51^{\circ} \mathrm{C}$ for 45 seconds, followed by 43 cycles each comprising a denaturation step at $94^{\circ} \mathrm{C}$ for 45 seconds, a hybridization step at $51{ }^{\circ} \mathrm{C}$ for 45 seconds and an elongation step at $72^{\circ} \mathrm{C}$ for 1 minute 30 seconds. The amplification products are denatured at $72^{\circ} \mathrm{C}$ for 10 minutes.

\section{RESULTS}

Figure 2 is an image of migration obtained with the primers VM22 and VM30 for the five studied lines. The markers VM22 and VM30 allowed the amplification of products PCR at the samples of target ADN. The sizes of the various fragments varied between $50 \mathrm{~Pb}$ and $200 \mathrm{pb}$. These two markers allowed to differentiate the homozygous from the heterozygous. Marker VM22 generated only of the same bands molecular weight with
Electrophoresis separation and visualization of PCR products: The PCR products have been separated on an agarose gel at $2 \%$ and containing the ethidium bromide (BET) use as fluorescent developer with the ultraviolet rays. The time of migration was one hour and was carried out in plug TBE $0.5 \mathrm{x}$ under a tension of $75 \mathrm{~V}$ and $50 \mathrm{~mA}$ (milliamp). The revelation of the products of amplification was made with the ultraviolet light (UV) thanks to a transiluminator in a dark room then photographed with a camera of mark Canon Power Shot A620, 7,1 Mega Pixels.

Polymorphism identification of the microsatellites markers (SSRs): It consisted in testing the capacity of the marker in revealing the resistant or significant phenotype of each of the five lines of cowpea. The markers that revealed the presence of specific bands or polymorphism were subjected to validation.

Identification of the microsatellite markers linked to the gene of resistance: The polymorphic markers were used for the identification of the markers related to the gene of resistance to CABMV. The markers selected were those which were codominant and dominant i.e. those having a polymorphism of the type absencepresence of bands not so fitting with the criteria of a microsatellite marker.

all the individuals. It was thus a marker monomorphic. However VM30 generated two polymorphic bands at 100 $\mathrm{Pb}$ and $200 \mathrm{~Pb}$ between the variety of cowpea sensitive Gorom local and the varieties resistant of cowpea $K V \times 396-4-5-2 D, K V \times 640, K V \times 61-1$ on the one hand and on the other hand between significant variety $K V \times 30-309-$ $6 \mathrm{G}$ and resistant $\mathrm{KV} \times 396-4-5-2 \mathrm{D}, \mathrm{KV} \times 640, \mathrm{KV} \times 61-1$. 


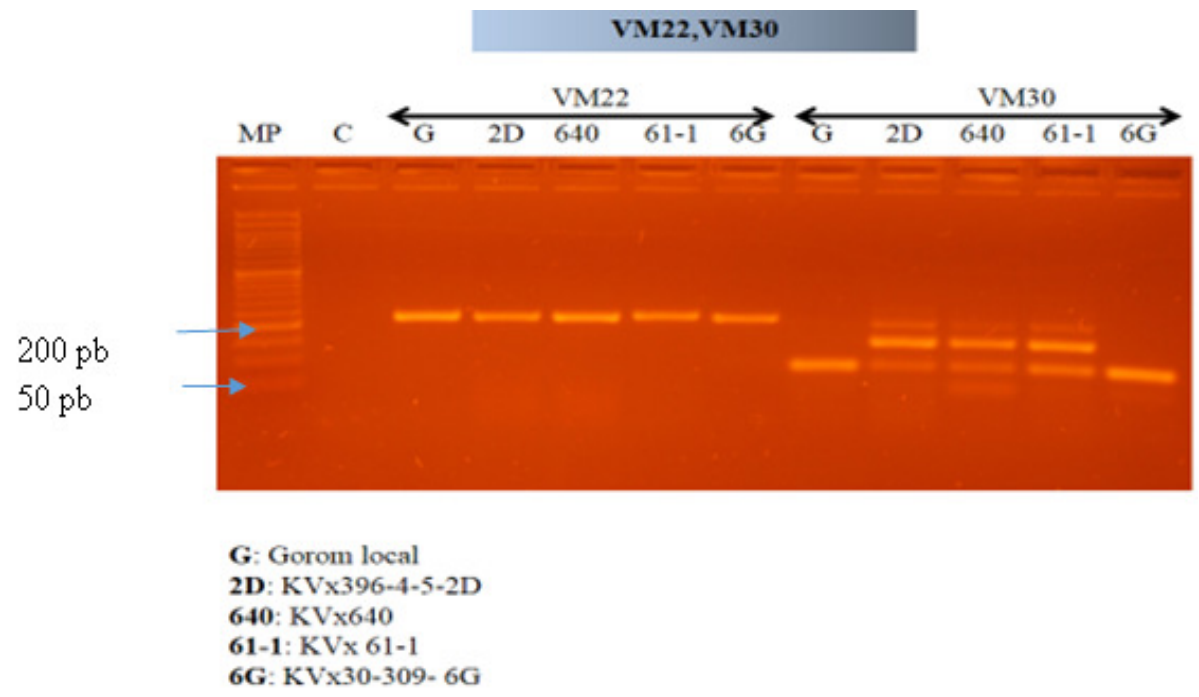

Figure 2: Profiles of products PCR of five genotypes of cowpea with the microsatellite primers VM22-VM30.

The results of the profiles of products PCR of five cultivars of cowpea with the couples of primers VM31 and VM37 are presented on figure 3. Two markers VM31 and VM37 used in this test allowed to amplify the DNA. With VM31, a band of size equal to 200pb was observed with all the genotypes of cowpea. In the same way, with VM37, a band of size equal to 300pb was observed with all the genotypes of cowpea. These two markers are monomorphic qualified markers.

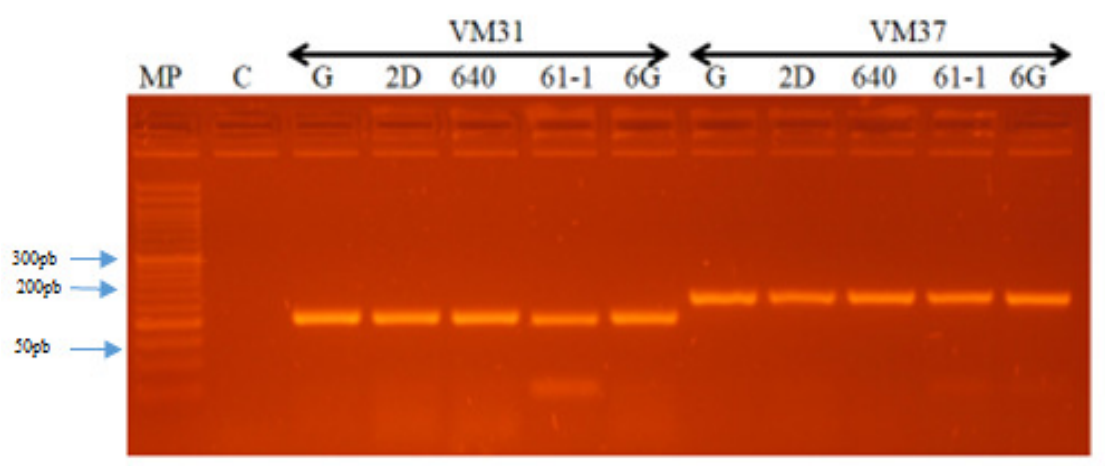
G: Gorom local
2D: $\mathrm{KV} \times 396-4-5-2 \mathrm{D}$
640: KVx640
61-1: KVx 61-1
6G: KVx30-309-6G

Figure 3:Profiles of PCR products of five genotypes of cowpea with the microsatellites primers VM31-VM37

Figure 4 is a profile of migration obtained with markers VM19, VM25 and VM68. All the markers used in this test permitted to amplify the DNA. The marker VM19 revealed a polymorphism of the presence-absence type of bands, it is a dominant marker. The marker VM25 revealed two bands, one to $150 \mathrm{~Pb}$ and the other to $250 \mathrm{~Pb}$ present with all the genotypes of cowpea- KVx30-309-6G, Gorom local, $\mathrm{KV} \times 61-1, \mathrm{KV} \times 396-4-5-2 \mathrm{D}, \mathrm{KV} \times 640$. This marker is known as monomorphic marker. On the other hand the marker VM68 revealed a polymorphism of loci with 600 $\mathrm{Pb}$ between $\mathrm{KV} \times 61-1$ and $\mathrm{KV} \times 640, \mathrm{KV} \times 396-4-5-2 \mathrm{D}$, 
Barro et al., J. Appl. Biosci. 2018 Selection and validation of marker set for selection of resistant varieties of cowpea to Cowpea Aphid-borne Mosaic Virus (CABMV) in Burkina Faso

KVx30-309-6G, Gorom local and with 500pb between Gorom local and KVx396-4-5-2D.

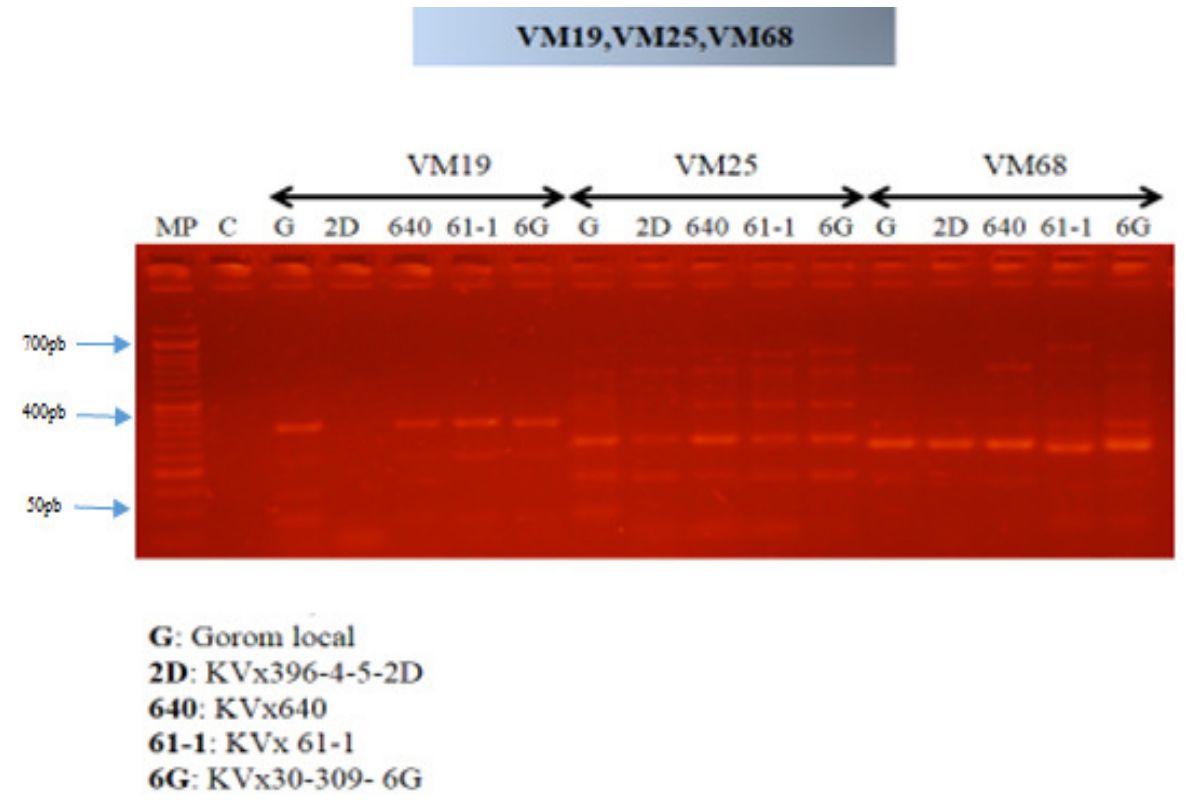

Figure 4: Profiles of PCR products of five genotypes of cowpea with the microsatellite primers VM19, VM25 and VM68

The revelation of polymorphisms of bands by the couples of the primers VM26, VM33 and VM70 enabled us to obtain the genetic profiles of the cultivars of cowpea indicated in figure 5. The markers VM26, VM70 and VM33 used in this test allowed to amplify the DNA, but the markers VM33 and VM70 revealed a polymorphism between the five parents.Indeed, the profile electrophoretic of the products of PCR amplification obtained starting from marker VM33 presents two polymorphic bands of which a band of size equal to
$500 \mathrm{pb}$ corresponding to the DNA amplified with all the parents, and another band of size equal to 600pb corresponding to the DNA amplified with the parent $\mathrm{KV} \times 61-1$ to intermediate resistance to the CABMV. With marker VM70, There is a polymorphism at $750 \mathrm{pb}$ between KVx640 and Gorom local, KVx61-1, KV×30-309$6 \mathrm{G}, \mathrm{KV} \times 396-4-5-2 \mathrm{D}$. The marker VM26 presented bands of the size at $300 \mathrm{~Pb}$ with all the genotypes of cowpea. This marker was monomorphic.

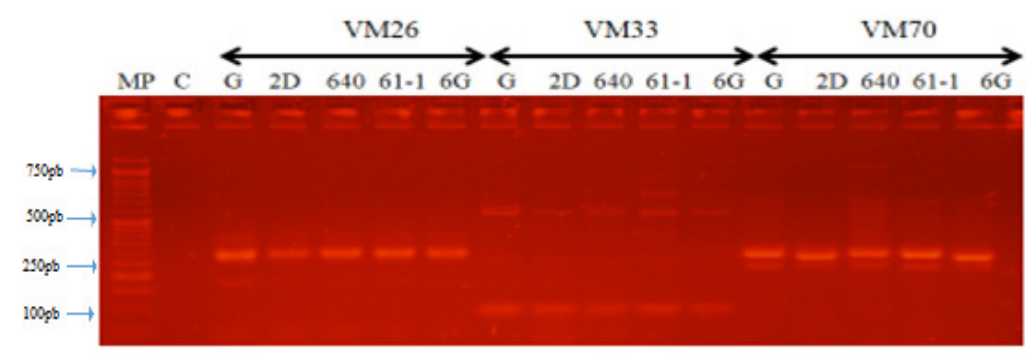

$$
\begin{aligned}
& \text { G: Gorom local } \\
& \text { 2D: KVx396-4-5-2D } \\
& \text { 640: KVx640 } \\
& \text { 61-1: KVx } 61-1 \\
& \text { 6G: KVx30-309- } 6 \mathrm{G}
\end{aligned}
$$

Figure 5:Profiles of PCR products of five genotypes of cowpea with the microsatellites primers VM26, VM33 and VM70. 
With the couples of primers VM3, VM5, VM11, VM12, VM13, VM14 and VM27, the genetic profiles of the five cultivars of cowpea are indicated to the level of figure 6. Of the seven markers used in this test, six made it possible to amplify DNA on the other hand (VM5, VM11, VM12, VM13, VM14 and VM27) but there was no amplification with the marker VM3. The markers VM5, VM11, VM12, VM13, VM14 and VM27 have bands of size equal to $150 \mathrm{~Pb}$ with all the genotypes of cowpea; they are thus monomorphic. It is the same for the marker VM14 that presented bands of size equal to $50 \mathrm{~Pb}$ with all the genotypes.

\title{
VM3,VM5,VM11,VM12,VM14, VM27
}

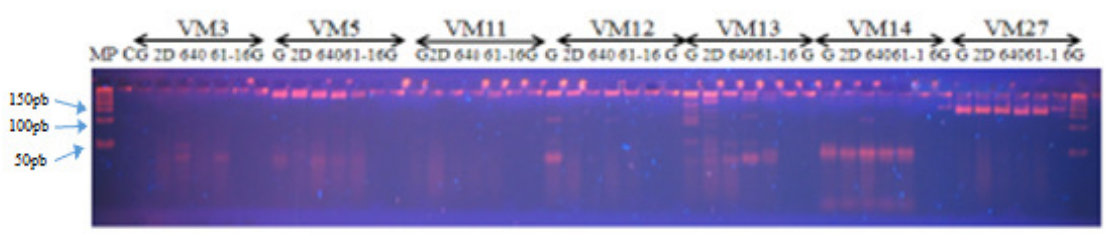

\author{
G: Gorom local \\ 2D: KVx396-4-5-2D \\ 640: $\mathrm{KV} \times 640$ \\ 61-1: KVx 61-1 \\ 6G: KVx30-309- 6G
}

Figure 6:Profiles of PCR products of five genotypes of cowpea with the microsatellite primers VM3, VM5, VM11, VM12, VM13, VM14 and VM27.

Identification of the markers linked to the gene of resistance to CABMV: In this study, 5 parents, namely, Gorom local, KVx30-309-6G, KVx61-1, KVx396-4-5-2D and $\mathrm{KV} \times 640$; five $\mathrm{F}_{1}$; Five $\mathrm{F}_{2}$ and $a \mathrm{BC}_{1} \mathrm{~F}_{1}$ of each combination were used. The result of the phenotype through a sifting with the CABMV of the five parents in greenhouse is presented in table 1.

Table 1:Result of the phenotyping

\begin{tabular}{l|ll}
\hline Lines & Genotypes & Statute \\
\hline Local Gorom & SS & Susceptible \\
KVx30-309-6G & SS & Susceptible \\
KVx61-1 & RS & Intermediary \\
KVx396-4-5-2D & RR & Resistant \\
KVx640 & RR & Resistant \\
\hline
\end{tabular}

This study aims at obtaining markers having bands, which segregate in a consistent way with the gene of interestthe resistance to the CABMV. Among the four identified polymorphic markers, two markers- VM68 and VM30 were used for the validation. These two markers were retained on account of their codominance. The figures 7 and 8 present the result of the amplification of the parental DNA as well as those of the heterozygous descendants (five $F_{1}$ individuals and five individuals
$\mathrm{BC}_{1} \mathrm{~F}_{1}$ ) and the homozygous (five $\mathrm{F}_{2}$ individuals) with marker VM68. The size of the bands is at 200pb with the parent of intermediate resistance, $\mathrm{KV} \times 61-1$ and at 250pb with the susceptible parent, $K V \times 30-309-6 G$. One $F_{1}$ individual over five, one $F_{2}$ individual over five and individual $\mathrm{BC}_{1} \mathrm{~F}_{1}$ present the statute of the sensitive parent and also one $F_{1}$ individual over five and one $F_{2}$ over five also present the statute of the resistant relative. The other individuals have a band much broader than 
those of the parents. The other $F_{1}$ individuals are heterozygous and $F_{2}$ of the homozygous. An absence of common band between the two parents was noted. This marker is described as codominant marker.

\section{VM68 pour le croisement 61-1 X 6G}

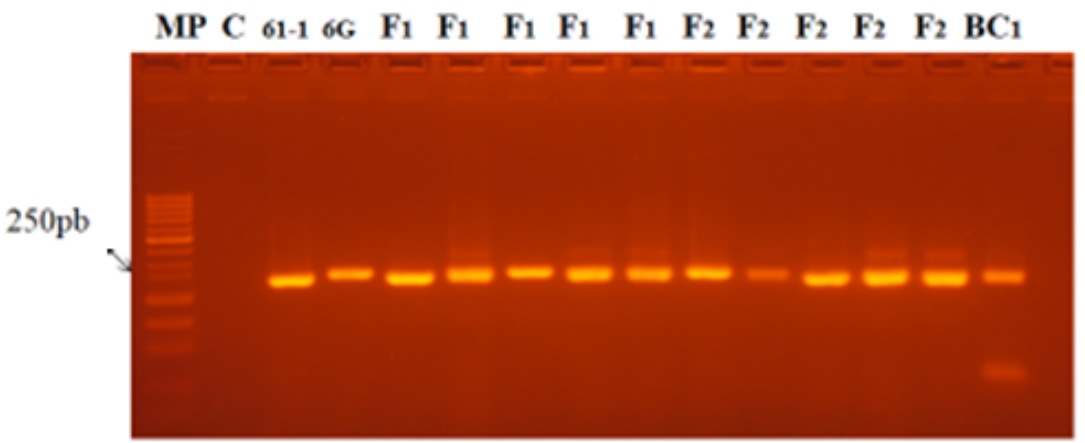

6G: $\mathrm{KVx} 30-309-6 \mathrm{G}$

61-1: KVx 61-1

Figure 7:Profile of PCR products of two genotypes of cowpea (KVx61-1;KVx30-309-6G) and their descendants with the microsatellite primers VM68.

The individuals resulting from the crossing between $\mathrm{KV} \times 61-1$ (intermediate resistance) and $\mathrm{KV} \times 640$ (resistant) to CABMV present all the same statute and have bands much broader than that of the parents. The size of the bands is at 200pb with $\mathrm{KV} \times 61-1$ and 250pb with $\mathrm{KV} \times 640$. No common band exists between the two parents confirming the codominance of the marker.

\section{VM68 pour le croisement $61-1$ X 640}

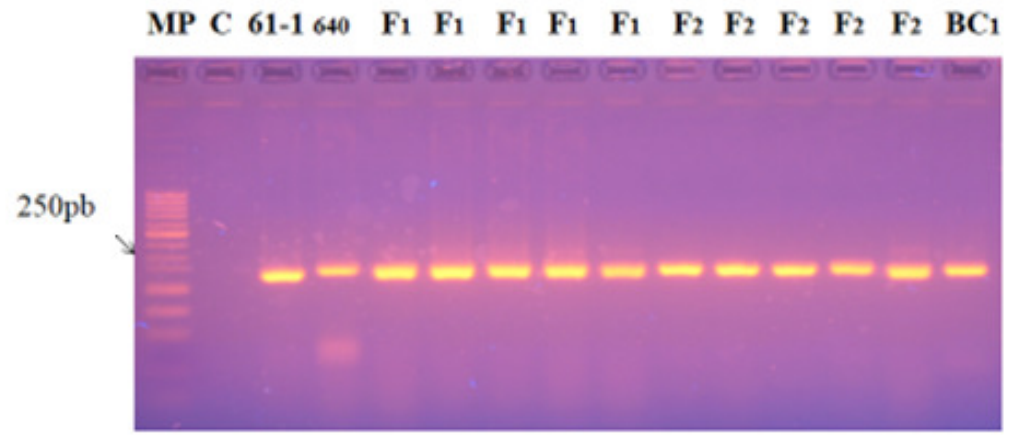

640: KVx640

61-1: KVx 61-1

Figure 8:Profile of PCR products of two genotypes of cowpea $(K V \times 61-1 ; K V \times 640)$ and their descendants with the microsatellite primers VM68. 
The figures 9,10 and 11 present the result of the amplification of the parental DNA as well as the one of the heterozygotes descendants (five $F_{1}$ individuals and the individuals $\mathrm{BC}_{1} \mathrm{~F}_{1}$ ) and homozygotes (five $\mathrm{F}_{2}$ individuals) with marker VM30. On figure 9 , all the individuals have the band of susceptibility present with the sensitive parent, local Gorom local. Three $F_{1}$ over five have the same statute as the parent $\mathrm{KV} \times 61-1$, intermediate parent, just as two $\mathrm{F}_{2}$ individuals and the individual $\mathrm{BC}_{1} \mathrm{~F}_{1}$. The two other $F_{1}$ individuals and the three $F_{2}$ individuals have on the other hand the statute of the sensitive parent. The size of the band with Gorom local is at 100pb and with $\mathrm{KV} \times 61-1$ at $150 \mathrm{pb}$. We notice the existence of a common band to both parents at 100pb. This marker is dominant and can be a potential candidate for the validation.

VM30 pour le croisement GL $\times$ 61-1

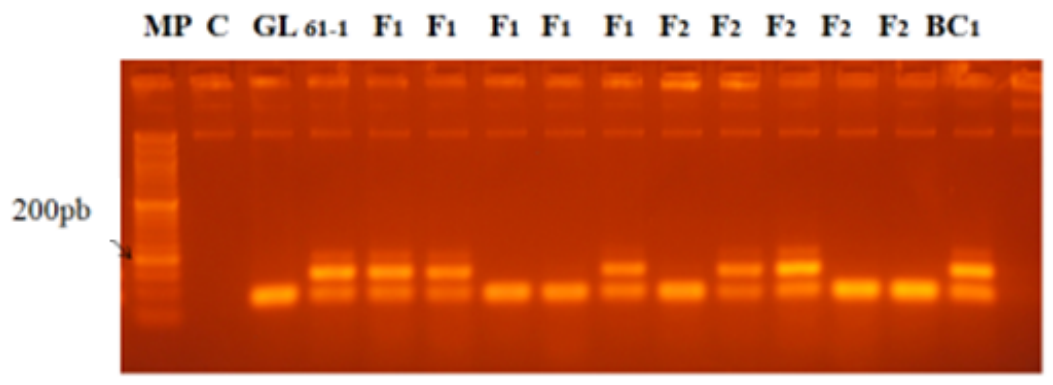

GL: Gorom local

61-1: KVx 61-1

Figure 9:Profile of PCR products of two genotypes of cowpea (local Gorom;KVx61-1) and their descendants with the microsatellite primers VM30.

With the Gorom local crossing by KVx640, the size of the band with the susceptible parent, Gorom local is at $50 \mathrm{pb}$ and at $100 \mathrm{pb}$ with the resistant parent, $\mathrm{KV} \times 640$. All the heterozygous individuals and homozygous present the susceptibility present band with the Gorom local parent at $50 \mathrm{~Pb}$ and the band of resistance with $\mathrm{KV} \times 640$ parent to
$100 \mathrm{pb}$. Two of the $\mathrm{F}_{2}$ individuals have the statute of the relative resistant and the three others the one of the sensitive parent. We also notice the existence of a common band between the two parents at $50 \mathrm{~Pb}$, which confirms the predominance of the marker VM30. 


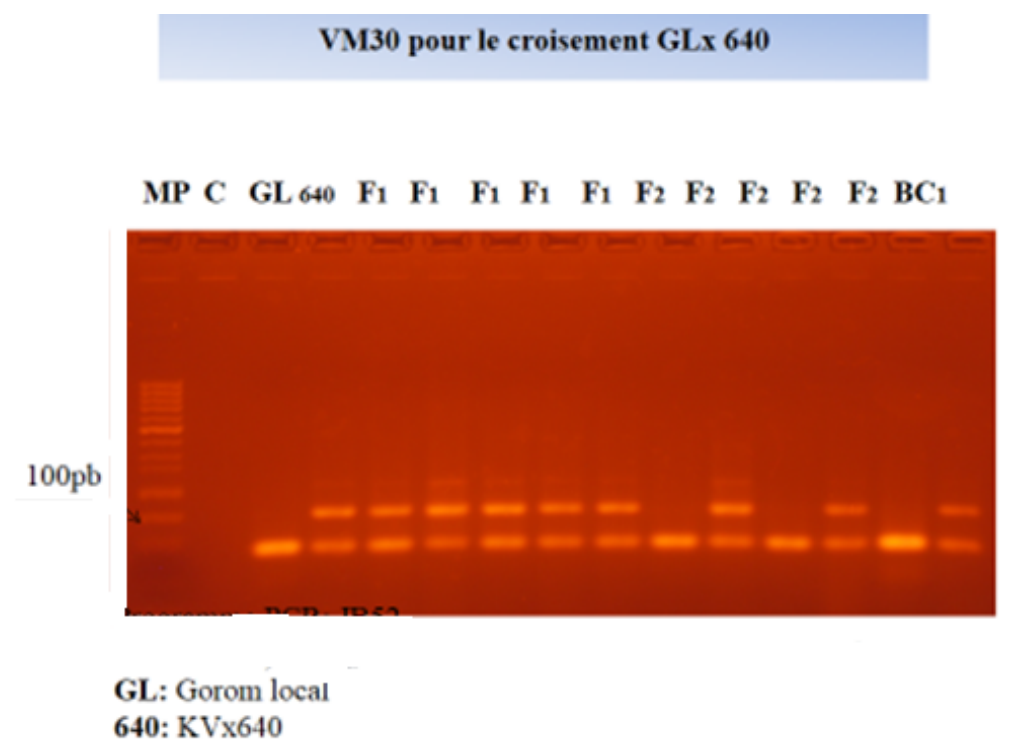

Figure 10:Profile of PCR products of two genotypes of cowpea (Gorom local;KVx640) and their descendants with the microsatellite primers VM30

On the figure 11 , all the descendants have the statute of the resistant parent $\mathrm{KV} \times 396-4-5-2 \mathrm{D}$ at $100 \mathrm{pb}$. The size of the bands is at $50 \mathrm{pb}$ with the sensitive parent $\mathrm{KV} \times 30-309$ -

$6 \mathrm{G}$ and at $100 \mathrm{pb}$ with the resistant parent $\mathrm{KV} \times 396-4-5-$ $2 \mathrm{D}$.

\section{VM30 pour le croisement $6 \mathrm{Gx} 2 \mathrm{D}$}

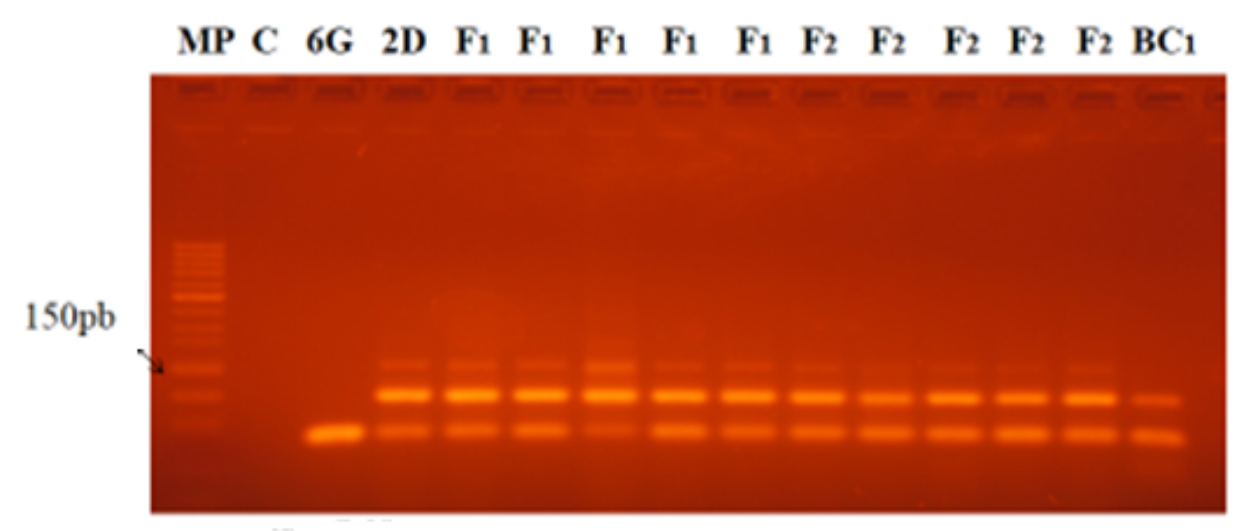

6G: KVx30-309-6G

2D: $\mathrm{KVx} 396-4-5-2 \mathrm{D}$

Figure 11:Profile of PCR products of two genotypes of cowpea (KVx30-309-6G ;KVx396-4-5-2D) and their descendants with the microsatellite primers VM30 
Barro et al., J. Appl. Biosci. 2018 Selection and validation of marker set for selection of resistant varieties of cowpea to Cowpea Aphid-borne Mosaic Virus (CABMV) in Burkina Faso

\section{DISCUSSION}

Polymorphism of the microsatellite markers loci for the resistance to CABMV: The molecular characterization of the amplified DNA fragments of five genotypes allowed identifying four (4) polymorphic microsatellite markers among the seventeen (17) that is a rate of $23.52 \%$ of polymorphism versus $76.47 \%$ of monomorphism. Thus, the markers VM30, VM33, VM68 and VM70 were polymorphic under the experimental conditions of Li et al., (2001), which are in agreement with that found by BARRO et al., 2016. However, two types of polymorphism fragments within these markers were noted. It is the polymorphism of the presence-absence type of bands for the dominant markers and polymorphism allowing the differentiation of the homozygotes from the heterozygotes. This result is in accordance with that found by Zida (2014) which worked on the striga. The sizes of the amplification products of these loci varied between 100 and $750 \mathrm{pb}$. These results are not in accordance with those found by Ouedraogo et al., in 2001 during the identification of markers AFLP linked to the gene of resistance to Striga gesnerioides with cowpea which had obtained a size of the amplified fragments ranging between 75 and $600 \mathrm{pb}$ and by ZIDA (2014) during the identification of polymorphic markers for the resistance to Striga which had also the sizes of the products of amplification of the loci which varied between 50 and 650pb.The results of Ouedraogo et al., 2001 would be linked to the nature of the AFLPs markers used, which is nonspecific and reveals the polymorphism in mass. The existence of bands or fragments at the same time present with the susceptible parents and the resistant parents could correspond to alleles of gene conferring the susceptibility to the CABMV. This result confirms that of Barro et al., 2016. Indeed the analysis of the DNA fragments amplified by certain pairs of microsatellite primers had shown the presence of two bands with the genetic profiles of the cultivars i.e. in the susceptible parents as in the resistant parents.

Identification and validation of codominant polymorphic markers: After the identification of the polymorphic markers, two markers have been finally retained allowing to distinguish the heterozygotes from the homozygotes. These markers were VM68 and VM30, undergoing thus a test of validation which consisted in checking the link between the selected markers and gene of interest present with the resistant genotypes. At the end of this test, the two markers proved to be associated in a consistent way to the gene of resistance to CABMV present with the genotypes KVx640, KVx396-4-5-2D.With the marker VM68, two types of alleles were obtained. For the combination $\mathrm{KV} \times 61-1, \mathrm{KV} \times 30-309-6 \mathrm{G}$ and their descendants, at 250pb is located the present allele with the sensitive parent, which would correspond to the recessive allele and $200 \mathrm{pb}$ the allele with the intermediate parent. In addition, for the combination $\mathrm{KV} \times 61-1, \mathrm{KV} \times 640$ and their descendants are at 200pb, the present allele with the intermediate parent and at 250pb with the resistant parent KVx640, which would show the dominant allele (resistant). With the marker VM30, three types of alleles were obtained with the genotypes Gorom local, $\mathrm{KV} \times 61-1$ and their descendants and the genotypes $K V \times 30-309-6 G, K V \times 396-4-5-2 D$ and their descendants. On the other hand, with genotypes the Gorom local, $\mathrm{KV} \times 640$ and their descendants, two types of alleles were obtained. The present allele with the parents Gorom local and $\mathrm{KV} \times 30-309-6 \mathrm{G}$ would correspond to the recessive allele and one of the present alleles with the resistant $\mathrm{KV} \times 640$ and $\mathrm{KV} \times 396-4-5-2 \mathrm{D}$ to the dominant allele. The amplification of the samples of DNA coming from the five genotypes from cowpea thanks to the couples of microsatellite primers has generated polymorphic fragments and codominants for each marker. The sizes of the various fragments varied between 200 and 250pb for the marker VM68 and between 50 and 250pb for the marker VM30. The amplification of the DNA of the different individuals by the reactions of polymerization in chains (PCR) provided an electrophoretic profile showing of the individuals $F_{1}$ and $\mathrm{BC}_{1} \mathrm{~F}_{1}$ bearing the parental alleles on the one hand at 200pb and at 250pb with the genotypes KVx61-1, KVx30-309-6G and their descendants and on the other hand for the genotypes KVx61-1, Gorom local for marker VM68. The marker VM68, identified during this study is thus linked to the gene of resistance to CABMV with the resistant genotype $\mathrm{KV} \times 640$ at $250 \mathrm{pb}$. This marker is codominant. Indeed, according to Ribaut and Hoisington (1998);KUMAR (1999), this marker can be used in a program of selection assisted by marker allowing to introgresse the gene of resistance to CABMV in the best lines.In the same way, the marker VM30 is also linked to the gene of resistance at $100 \mathrm{pb}$ with $\mathrm{KVx} 640$, resistant parent and at $50 \mathrm{pb}$ with the sensitive parent, Gorom local. The marker VM30 showed the existence of a common allele to the parents at $50 \mathrm{pb}$ and $100 \mathrm{pb}$. This marker is dominant and does not have a great interest when it comes to assisted selection by markers. 


\section{CONCLUSION}

The polymorphic markers related to the resistance to CABMV with the cowpea were identified and validated. The molecular characterization of the amplified DNA fragments of the five genotypes of cowpea made it possible to identify four (4) polymorphic microsatellite markers among the seventeen (17), that is to say a rate of $23.52 \%$ of polymorphism versus $76.47 \%$ of monomorphism. These markers were VM30, VM33,

\section{REFERENCES}

Barro A., 2013. Evaluation génétique de la résistance de quelques lignées et écotypes de niébé (Vigna unguiculata (L.) WALP.) au Cowpea AphidBorne Mosaic Virus au Burkina Faso. Mémoire de DEA. , Université de Ouagadougou, 37p.

Barro A., Tignegré J-B.S., Kiébré Z., Drabo I., et Sawadogo M., 2016. Identification of Polymorphic Microsatellite Markers Linked to Cowpea Resistance to Cowpea Aphid Borne Mosaic Virus (CABMV) in Burkina Faso. Int.J.Curr.Microbiol.App.Sci. 5(6): 399-405.

Kumar LS., 1999. DNA markers in plant improvement: An overview. Biotechnology Adv 17:143-182

Li C-D., Fatokun C.A., Ubi B., Singh B.B., Scoles G.J., 2001. Determining Genetic Similarities and Relationships among Cowpea Breeding Lines and Cultivars by Microsatellites Markers. Crop Sci. 41, 189-197.

Orawu M., 2007. Occurrence of cowpea aphid-borne mosaic virus and prospects of improving resistance in local cowpea landraces in Uganda. Thèsis, University of KwaZulu-Natal, 137p.

Ouedraogo J.T., Maheshwari V., Berner D.K., ST-Pierre C.A., Belzile F.J. ET Timko M.P., 2001. Identification of AFLP markers linked to resistance of cowpea (Vigna unguiculata L.) to parasitism by Striga gesnerioides. Theoretical and Applied Genetic 102: 1029-036.

Ribault J.-M., and Hoisington D., 1998. Marker-assisted selection: new tools and strategies. Trends Plant Sci. 3: 236-239.

Young N.D., 2000. A cutiously optimistic vision for marker-assisted breeding. Mol. Breed. 5: 505510.

Zida W. F., 2014. Identification et validation de marqueurs microsatellites associes au gene de resistance a la race $\mathrm{sg} 1$ de striga gesnerioides (willd.) Vatke. Chez le niebe (Vigna unguiculata (l.) Walp.). Mémoire de Master. , Université de Ouagadougou, 52p.
VM68 and VM70. Two of the polymorphic markers- VM68 and VM30 underwent the test of validation based on their codominance. At the end of this test, VM68 was codominant and VM30 dominating. The marker VM68 allowed to distinguish the individuals heterozygous $\left(\mathrm{F}_{1}\right.$, $\left.\mathrm{BC}_{1} \mathrm{~F}_{1}\right)$ from the individuals homozygous $\left(\mathrm{F}_{2}\right)$. This marker is validated and can be proposed with the varietal selection of cowpea for resistance to the CABMV. 